\title{
初めての出産，育児をしている女性の生きられた体験
}

\section{Lived experiences of child-rearing women after first childbirth}

\author{
鄭香 苗 (Kanae CHONG) *1 \\ 谷口初美 (Hatsumi TANIGUCHI) $* 2$
}

抄 録

目 的

女性にとってのはじめての育児体験をありのままに記述し，はじめての育児体験が女性自身の人生へ もたらす意味について探求すること。

\section{対象と方法}

出産後8か月を経過した初産婦 10 名を対象に非構造化インタビューを実施した。得られたデー夕は, Colaizziの方法による記述的現象学的アプローチによって, 質的分析ソフトNVivo11を使用し分析をお こなった。

\section{結 果}

はじめての育児体験が女性自身の人生にもたらした意味として,【子どもを持ってはじめて感じた周 囲からのまなざし】、張りつめた日々から子どもとともに生きる親としての日常】、探し求めている充 実感】のつのカテゴリーが抽出された。

はじめての育児を行う女性は，育児の楽しさと同時に負担感も感じる体験をし，親であることへの迷 いや不安を抱きながら，親として生きること以外に個人としての充実感も求めていた。育児をするなか で困難と感じる状況では，家族や周囲の人との関わりの中で，自分を見つめる時間をもつことで，これ までには気が付かなかった新たな価值観を獲得していた。

\section{結 論}

3つのカテゴリーから得られた育児期女性への助産ケア実践への示唆として，育児期にある女性が, 自分の人生において育児体験の意味をどう捉えているかを理解し，支援を行うことが大切である。ま た，育児期女性への支援は，育児期女性のみに向けられるのではなく，女性の家族や周囲の人をも含め た支援として考えていく必要がある。

キーワード : 育児体験, 女性個人，初産婦，現象学的アプローチ

\section{Abstract}

\section{Purpose}

This study aimed to explore the meaning of the lived experiences of child-rearing women after first childbirth,

*1 福岡女学院看護大学 (Fukuoka Jo Gakuin Nursing University)

*2 九州大学大学院医学研究院保健学部門 (Department of Health Sciences, Faculty of Medical Sciences, Kyushu University) 2019 年 9 月 21 日受付 2020 年 4 月 1 日採用 2020 年 6 月 30 日公開 
with describing their experiences of child-rearing as they are.

\section{Method}

The study employed a descriptive phenomenological approach with in-depth interviews. Participants included 10 primiparas, eight months after having given birth. Employed Colaizzi's model and NVivo11 for analysis.

Results

The major findings of this study consisted of 3 thematic categories: "The attention of surrounding people since having the child;" "The determination to live together with child through the tense days long-term;" "Looking for satisfaction with my own life." Participants became able to face themselves through the difficulties of childrearing, and through relations with the people around them. Consequently they acquired new values in life, being not able to notice so far.

\section{Conclusion}

These findings suggest it is important to support child-rearing women how they catch the meaning of their child care experiences. It's necessary to be considering care to a woman during the child-rearing period as support of the family and the surrounding person of the woman, not to be turned to only herself, when a midwife care for a woman during the child-rearing period.

Key words: child-rearing, personal-self of women, primiparas, phenomenological approach

\section{I。緒言}

生殖医療技術の発展や女性のライフコースの多様化 に伴い, 現代女性にとって子どもを産み育てること は，自然に授かるものというより選択的なライフ コースの一つとなっている（柏木，2001）。育児を行 う現代女性は, 自分が望んで選択した子どもだからこ そ，自分の手で充実して育てたいという気持ちも強 く, 同時に子育てばかりではなく, 個人としての自分 の人生も充実させたいという意識も持っている（井 上，2003；大日向，1988）ことも指摘されている。小 野田 (2013) は，育児期女性の「個人としての自分」の 理想度と実現度について質問紙調査を行い，育児期の 女性は，個人としての時間や世界を持ちたいと強く願 いつつも実際にはそれが実現されていないという ギャップが大きかったことを報告している。妊娠・出 産するまで, 人生の多くの場面で主体的な選択をして 生きてきた女性が，なかなか思い通りにはいかない育 児に直面し, 戸惑いを感じることは想像に難くない。 女性にとって, 出産・育児期は, 「個としてのアイデ ンティティと母親としてのアイデンティティの葛藤が 顕在化する時期」(岡本，1996）であり，自らにとつて の子育ての意味をどう考えるかによって出産後の女性 のアイデンティティ再構築に影響を与えることが推測 される。育児をする女性の自尊感情の低さからもたら される被害的認知は, 虐待的行為に影響を及ぼす (中 谷他，2006）という知見からも，育児期女性が，今子 育てをしている自分をどのように感じているか理解す ることは意義あることと考える。
育児期の女性についてのこれまでの研究の多くは, 対象女性を「母親」として, 子どもの健全な成長・発 達のための影響要因として捉えてきた（柏木他， 1994 ; 戸田，2009）。子どもにとつての母親の「母性」 を考える視点は重要なことであるが，育児期女性への 支援を考えるとき，山崎 (1997) が指摘するように, 女性にとって一つの側面にすぎない母性に傾倒し過ぎ ることは，育児期女性を全人的に捉え損ねる危険性も 孕んでいる。徳田 (2004) は, 女性にとっての子育て の意味づけが成長や学びとして語られたときに，育児 による自己の成長が，単純な成長実感としてだけでな く,「母親によって, 果たすべき義務や達成すべき課 題として捉えられる可能性」を指摘している。それ は，すなわち育児に伴う負担感や大変さは母親である ならば乗り越えるべきもの，という考えを含んでいる と言い換えることもできる。「母親として」の振舞いを 期待される女性は, 周囲からの子育ての重圧を自身に 課している場合もあるであろう。母親として」という 概念は, 時代や社会, 文化からの影響も受けて規定さ れる面がある。子育てをおこなう女性が, 周囲から 「母親」として認知され，母親になっていくという側 面がある一方, 人生において初めての体験となる子育 てをどのように感じ体験しているのか率直な感覚を理 解することは，子育てをおこなう女性を支援する際の 必要な視点だと考える。

そこで, 本研究では, 出産に続いて育児をおこ なっている女性を「母親」としてとらえる視点を一度 棚上げにし，現代に生きる女性は育児をどのように体 験しているのか, 現代女性とっての育児体験をありの 
まま記述し，その体験が女性の人生にもたらした意味 を探求することを目指した。

大人も子どもと同様に新しい経験に出会い，新しい 役割の中で生涯発達をしていく（柏木他，1994）とい う視点を持ちながら，一人の個人としての女性が出産 して育児を経験するという「私自身が感じる育児体 験」の観点を大切にして女性の体験をありのままに記 述し，育児体験が女性の人生にもたらした意味を探求 することを目的とした。

\section{II．用語の操作的定義}

育児：産後8か月ころは，母親役割を自己統合でき るようになる (Mercer, 1981 ；Rubin, 1986/1997) 時期 との文献検討の結果から, 本研究では研究参加者を産 後8か月の子どもをもち，育てている女性として選定 した。従って，本論文における「育児」とは，自らの 出産に続いて生後8か月まで出産したわが子を継続的 に育てること，と操作的定義をする。

\section{III. 研 究 方 法}

\section{1. 研究デザイン}

初めて出産をした女性の育児体験をありのまま記述 し，その体験が女性の人生にもたらした意味を探求す るため，記述的現象学的アプローチを用いた。記述的 現象学アプローチの主目的は, 「日常経験の現象の本 質的な構造を理解するために，そうした現象を網羅的 に記述すること」(Holloway et al., 2002) であり，現象 学的探求は，普通は当たり前のことと思われている生 きられた経験を吟味し, 認識するための一助となるア プローチ方法である。

\section{2. 研究参加者}

$\mathrm{A}$ 県 $\mathrm{B}$ 産科クリニックにて, 経腟分娩により出産し た 20 歳以上の初産婦を対象とした。B産科クリニック 責任者からの紹介を経て, 研究者が1か月健診時にリ クルートを実施し，同意を得た女性を対象とした。妊 娠期から研究実施までに，合併症や障害をもつ母子は 除外基準とした。

質的研究のサンプリングについては，多様性を考慮 しながら「個」の理解を最大限まで深めていく(Sandelowski, 1995/2013) 必要があるとされている。本研究 過程では，9名のインタビュー終了時点でそれまでの
内容に新規性の少ないデー夕の飽和を感じた。データ の飽和確認のため, さらに継続し参加者 10 名の時点 でデータ収集を終了とした。

\section{3. 調査期間と研究期間}

調查期間は倫理審査委員会承認 (承認番号 : 28422）から 2018年 2 月 28 日までとし，研究予定期間は 2019年3月31日までとした。

\section{4. データ収集方法}

デー夕収集は非構造化インタビューと参加観察を実 施した。まず，パイロットスタディを行い，インタ ビュー手順や内容，問いかけの仕方なぞを検討し，修 正後デー夕収集を実施した。

1）パイロットスタディ：B産科クリニックのベ ビーマッサージ教室に来院した産後女性 5 名に対 し，同意を得て予備的にインタビューを実施し た。逐語録から，インタビュー内容，問いかけ の方法，フィールドノートの記載方法について質 的研究専門家のスーパーバイズを受け, 研究参加 者のより深い体験の語りを引き出すため，それぞ れの方法について検討，修正をおこなった。

2）研究参加者への説明と同意：1か月健診時に待ち 時間を利用し，同意説明文書を用いて対面で説 明を行い，署名による同意を得た。インタ ビュー実施までに，印象的な出来事を記載でき るようミニノートを手渡した。ミニノートの使 用目的は, 研究参加者がインタビューを受ける 際に, 記憶を確認するためであり, 記載は強制 ではないこと，研究者は見ないことを伝えた。

3）研究参加者との関与：4か月健診頃に，母子の健 康状態および研究参加継続について各研究参加 者に連絡をとり確認をおこなった。インタ ビュー実施の 1 か月前に日時, 場所について希 望を確認し, 調整後決定した。

4）インタビュー時期：インタビュー時期は, 出産 後8か月とした。産後8か月ころは，母親役割を 自己統合できるようになる (Mercer, 1981 ; Rubin, 1986/1997）時期とされる。この頃の乳児の 発達から，母親を認識した愛着を示し，身体活 動も活発となり, 育児において新たな課題が生 じてくる（宮中，2001）時期であり，育児期女性 が母親となっていく自己を認識する過渡期でも あると考えた。そのため，この時期の女性は， 
自分自身について，また育児体験についても考 える契機を持てる時期ではないかと予測し，産 後8か月をインタビュー時期として設定した。

5）インタビューの実施：自宅以外でのインタ ビュー場所を希望した参加者には個室を準備し， 30 分 1 時間程度の非構造化インタビューをお こなった。インタビュー開始時に「今回初めて の妊娠，出産を経て，8か月間育児を体験してき た生活を振り返って頂き，その中で感じたこと や印象に残っていることなどをお話いただけま すか」と問いかけ，その後は参加者の話しの流 れに任せた。その際に，話している参加者の世 界をできるだけイメージするように努めた。現 象学的なインタビューでは, 先入観がバイアス となるため, インタビュー過程において, 参加 者の育児をおこなう生活について「母親として」 という視点について，できるだけ研究者自身の 考えや感情を一時棚上げするように意識し，括 弧入れ (判断留保) するように努めた。インタ ビュー内容は参加者の同意を得て ICレコーダー に録音し，逐語録を作成して研究データとした。

6）研究参加者の属性：インタビュー終了後, 年齢, 学歴, 妊娠中の気持ち等についてフェイスシー トに記入してもらった。

\section{5. データ分析方法}

現象学的看護研究で用いられる Colaizzi の7つのス テップ (Colaizzi， 1978) に従い, 分析をおこなった。 はじめに逐語録を繰り返し読み，参加者から語られた 世界を理解するよう努めた。逐語録から女性の育児体 験についての重要発言を抽出し, 不明な点は研究参加 者に確認をし, 詳しい説明を付加した意味付けをおこ なった。

以上のプロセスを繰り返し，意味づけをした重要発 言に，それぞれテーマ付けをおこなった。テーマを意 味のまとまりごとに整理しクラスターに分類し，逐語 録を確認しながら妥当性の検討を繰り返し，最終的に 得られたクラスターを集約してカテゴリーに分類し た。重要発言にテーマづけをし，整理するまでの段階 で質的分析ソフトNVivo11を用いた。最終段階（又 テップ7)で, 全ての参加者に得られた結果をフィー ドバックして確認を求め, 内容の正確性を検証した。 分析過程全ての段階において, 複数の研究者で妥当 性，信頼性の検討と修正をおこなった。フェイス
シートに記入された研究参加者の属性については, 各 項目について Microsoft Excel 2013 を用い, 単純集計 をおこなった。

\section{6. 真実性の確保}

質的デー夕の信憑性 (trustworthiness) を高める方法 については, Lincoln, et al.（1985）が述べている4つの 基準, 信用性 (credibility), 転用可能性（transferability), 明解性 (dependability), 確認可能性 (confirmability）に沿って評価をし，その確保に努めた。本研 究では, 研究参加者との長期関与による継続性, 参加 者の発言は参加者自身による体験の緻密な記載に基づ いていること, 分析最終段階での参加者による内容の 同意，フィールドノートの記載による方法の質的トラ イアンギュレーションを行い真実性の確保に努めた。

\section{7. 倫理的配慮}

インタビュー時にはプライバシーに配慮し個室を準 備して行うこと, インタビュー内容はICレコーダー に録音すること, 得られたデー夕は厳重に管理するこ となどを説明し，同意を得たのちに同意書に署名を得 た。

本研究は九州大学医学系地区部局臨床研究倫理審査 委員会の承認を得て実施した。(承認番号 : 28-422)

\section{IV. 結 果}

\section{1. 研究参加者の概要}

本研究参加者は最終的に 10 名となった。フェイス シートの記入を集計した結果は以下のとおりであっ た。年齢は $24 \sim 41$ 歳, 平均年齢は 32.2 歳であり, 妊 娠中に退職した者も含め全員就業経験があった。ま た，今回の妊娠については，全員が希望した妊娠であ り, 最終学歴は, 大学院卒業 1 名, 大学卒業 4 名, 短 期大学卒業 1 名, 専門学校卒業 1 名, 高校卒業 3 名で あった。インタビュー時間は，一人当たり 35 分〜 69 分, 平均 50.7 分であった。研究同意を得た際に記載を 依頼したミニノートを持参した参加者は 3 名, 育児日 記などその他のノートを持参した参加者は 4 名で あった。

\section{2. 出産に続く育児体験が女性の人生にもたらした意 味について \\ インタビュー結果の分析から, 出産に続く育児体験}




\begin{tabular}{|c|c|c|}
\hline カテゴリー (3) & クラスター (6) & テーマ(12) \\
\hline \multirow{2}{*}{$\begin{array}{c}\text { 子どもをもってはじめて感じた } \\
\text { 周囲からのまなざし }\end{array}$} & 人のあたたかさで支えられた理想とは違った現実 & $\begin{array}{l}\text { 楽しいばかりではない育児 } \\
\text { 困ったときに支えられた周囲の言葉と理解 }\end{array}$ \\
\hline & 子どもをもつことで感じた社会の敩しさと孤独 & $\begin{array}{l}\text { 意識する世間の冷ややかな視線 } \\
\text { 育児をして遠ざかる社会とのつながり }\end{array}$ \\
\hline \multirow{2}{*}{$\begin{array}{c}\text { 張りつめた日々から子どもとともに } \\
\text { 生きる親としての日常 }\end{array}$} & 子どもとともに生きる態度と決意 & $\begin{array}{l}\text { 子どものために発揮する挑戦のエネルギー } \\
\text { 親として存在する不確かさ }\end{array}$ \\
\hline & 深まるわが子への愛しい気持ち & $\begin{array}{l}\text { いつも心にいる離れがたいわが子 } \\
\text { 唯一の存在である私を求めているわが子 }\end{array}$ \\
\hline \multirow{2}{*}{ 探し求めている充実感 } & ひとりの個人としての私 & $\begin{array}{l}\text { 自分にとって意味ある時間 } \\
\text { 育児以外での自分の価値 }\end{array}$ \\
\hline & 自分自身を見つめること & $\begin{array}{l}\text { 見えてきた過去の自分の姿 } \\
\text { 広い視野で考える余裕 }\end{array}$ \\
\hline
\end{tabular}

が女性自身の人生にもたらした意味として，【子ども をもってはじめて感じた周囲からのまなざし】、【張り つめた日々から子どもと生きる親としての日常】、【探 し求めている充実感】のつのカテゴリーが見出され た。それぞれのカテゴリーについて，女性自身の人生 にとっての育児体験の意味を代表している重要発言を 示し，記述する (表1)。

カテゴリーは【】，クラスターは《》，テーマは 〈〉を用いて記述した。それぞれの代表的な重要発 言は斜体を用いて記述し，その発言をした研究参加者 をPと表記した。（）内の言葉は状況を補足するた め, 研究者が記載した。

1 )【子どもをもってはじめて感じた周囲からのまな ざし】

このカテゴリーでは子どもをもったことによって, はじめて意識した周囲との関わりや育児をする自分に 向けられる周囲からの視線について語られ，《人のあ たたかさで支えられた理想とは違った現実》、《子ども をもつことで感じた社会の厳しさと孤独》という $2 つ$ のクラスターで構成された。

クラスター《人のあたたかさで支えられた理想とは 違つた現実》は，2つのテーマ〈楽しいばかりではない 育児〉と〈困ったときに支えられた周囲の言葉と理解〉 で構成された。このクラスターでは, 子どもとの生活 が楽しい毎日だろうと考えていた参加者らが，思って いたのとは違う現実を感じた時の気持ちや困った時に 自分の気持ちを支えられたと感じた体験について語ら れていた。

以下代表される重要発言のように，子どもの成長を 見て育児が楽しいと感じる反面〈楽しいばかりではな い育児〉も意識され，楽しかった過去の時間が失われ
てしまったように感じていた者もいた。

$\mathrm{P}$ ：産んでよかったあーって, 楽しい, 可愛いって気 持ちありますけど，なんて言ったらいいんですか ね? あの時 (妊娠前) に戻れるなら戻って楽しみた い。けぞ, こっち(今の生活)には戻ってきたい。 この参加者は，食べたい時に好きなものを食べに行 き，お気に入りの洋服を着て気ままに出かけるような 些細な日常の楽しみが今はできなくなったと語り，以 前の生活に戻りたいと感じる気持ちと育児をする今の 生活との間で摇孔動いている心情について「あの時に 戻れるなら戻って楽しみたい。と発言していた。

$\mathrm{P}$ ：楽しい，けぞ(楽しいということを) 時々忘れそう になる，っていう感じですか稀。(子ぞもが) 毎日 どんどん，新しいことを見せてくれる，そういう 時は楽しいって思光りげむしろ，なんかいつも より，泣く，ぐずりやすい，っていうときとかは。 この参加者は, 子どもの成長を感じるときは楽しさ や喜びを感じるが，毎日が単調と感じられたり子ども の機嫌がよくない時は楽しいという気持ちにはなれな いと感じていた。

また，〈困ったときに支えられた周囲の言葉と理解〉 というテーマでは, 育児を負担と感じ困難と思う状況 の時，夫や実母からかけられた何気ない言葉や育児の 大変さに理解を示す態度によって，気持ちが支えられ たことが，以下のように語られた。

$\mathrm{P}$ ：(夫は)『女の人ってすごいな』つて言ってますね。 『こんなに大変』，おつぱいと夜中起きたりとか, 痹かしつけも『ああ，こんなに大変，洋服ひとつ 着せるのにもこんなに大変なんだ』とか。

$\mathrm{P}$ ：子育て楽しみって思ってたけど，そればっかり じゃないこともいっぱいあって，なんでこんなに 
泣くんやろう，とかいう時に，母が何気なしにか けてくれる言葉とか，ちょつと面倒みてくれて 『お風吕ゆっくり入って』，とか言ってくれるのが すごい(ありがたい)。(言葉に詰まり淚ぐむ)

クラスター《子どもをもつことで感じた社会の厳し さと孤独》では，子どもをもつてから職場で泠たい目 で見られた体験や，育児をしている状況が孤独感を生 み出していた体験が語られていた。このクラスター は, 〈意識する世間の冷ややかな視線〉, 〈育児をして遠

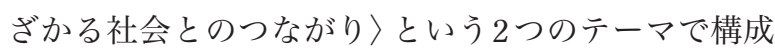
された。意識する世間の冷ややかな視線〉という テーマを代表する発言は以下の通りであった。

$\mathrm{P}$ ：育児休腵を終えて，職場に復帰するんですけど, 立場が弱いじゃないですけど，そういうのを良く 思わない人が多いというか, (中略) 私は戻る気 満々なのに，并ういうこと言われたのでけっこう 怒って帰ってきましたね。

この参加者は, 子育てしながら働くことを応援して くれると期待していた上司から，育児休㗇後の復職を よく思わない人もいる，と告げられた時の自分の気持 ちを語っていた。子育てをしながら㗢くことを快く思 わない同僚の存在や，それを自分に伝えた上司から も，自分が歓迎されていない冷ややかな視線を感じて いた。出産前と同様仕事を頑張ろうと思っていた参加 者は, 職場での周囲の反応から自分が置かれた立場 が，以前と同じょうには働けない人という「弱い立 場」に変化していくことを感じ，そのように周囲から みられていることに納得できない憤慨した気持ちを抱 いていた。

〈育児をして遠ざかる社会とのつながり〉という テーマは，以下の重要発言に代表された。

$\mathrm{P}$ ：かなり，切り離された感覚，外と，社会と。(中 略) 会社の人とかも, 今頃はバリバリ働いてて, 私だけ，なんか家で一人でダラダラしてる，って。 毎日会話してた人たちが, もう私のことを全然忘 れていくんだううなあ，と思うと，惄しいとか。

子どもと二人きりで過ごす日常の中で, 自分も以前 はそこで日々を送っていた社会生活から断絶されてい る，という感覚になった体験が語られていた。

2 )【張りつめた日々から子どもとともに生きる親と しての日常】

このカテゴリーでは，慣れない育児に周囲からの支 えを得て奮闘していた日々から変化し, 子どもと過ご す日常が自分にとってどのようなものとなっているか
が語られた。このカテゴリーは,《子どもとともに生 きる態度と決意》、《深まるわが子への愛しい気持ち》 という2つのクラスターで構成された。

クラスター《子どもとともに生きる態度と決意》で は, 子どもとともに過ごしていることによって, 自分 がどのような考えと態度で, どう生きるのか語られ, 果たして今の自分は子どもにとって正しいといえる育 児が出来ているのか模索していることが語られた。こ のクラスターは〈子どものために発揮する挑戦のエネ

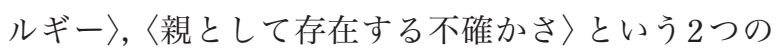
テーマから構成された。

〈子どものために発揮する挑戦のエネルギー〉とい うテーマでの代表的な発言は以下の通りであった。

$\mathrm{P}$ ：私あんまり人が好きじゃないんですよ。でも， やっぱこの子がおったら人見知りとかしてられん し，ちょっと，ちょっと頝張ってみたんですよ。 碩張った甲斐あって, 少し, 仲いい人が（でき た)。この人を通して人間関係が変わって(自分 は）強くなったなあ，って思う!

人付き合いに苦手意識があったこの参加者は, 子ど ものために社交的になろうと努め，新たな友人を得る ことになった。わが子の存在が, 参加者の背中を押し て, 新しいことに挑戦しょうというエネルギーを生 み, 参加者自身が以前より「強くなった」自分を意識 していた。

また，次の発言のように子どもの未来を見据えて今 までの自分の生活を見直していかなければならないと 考えた参加者もいた。

$\mathrm{P}$ ：今までひとりの時は，ほんとにどうでもいいやっ て思ってたけど，守るものができるとね，やっぱ 頑張んなきやいけないなっていうのと, (中略)も うこれから先この人の未来があるから, 慎重にコ ツコツとちゃんとやっていかなくゃな,って。

子どもとともにいる自分の生きる態度を考えて行動 すると同時に, 参加者の中には, 自分の行うことが子 どもにとって正しいことであるのか, 不安にも感じ, 〈親として存在する不確かさ〉について以下のように 語つていた者もみられた。

P：どういう方法で(子どもと）遊んでいいのかなあ, とかですね，それが本当に正しいのか，正しくな いのか, 誰も教えてくれないからですね。

この女性は, 自分の親としての子どもとの関わりが 「本当に正しいのか, 正しくないのか」常に自分で判断 し，考えねばならない不確かさに不安を抱いていた。 
$\mathrm{P}$ ：日々なんか，ただ毎日(子ぞもと)一緒にいて，ま あちょつと手を抜くことを覚えたな，とは思いま すけど，もう私，母親になったっていう感じまだ しない。

この参加者は，家事や仕事，育児と全て自分の理想 通りにするには無理があると気づき「手を抜くことを 覚えた」と語り，そのような自分が，果たして「母親 になった」のか，親としての自分に確証をもてないこ とを語っていた。

クラスター《深まるわが子への愛しい気持ち》では, 一緒にいない時でも，〈いつも心にいる離れがたいわ が子〉を気にかけていること，また〈唯一の存在であ る私を求めているわが子〉というテーマとして，自分 がわが子から最も求められている存在であることにつ いて語られた。それぞれのテーマを代表する発言は以 下のとおりであった。

$\mathrm{P}$ ：一緒にいなくても，やっぱり子どものことを考え てますね。今，泣いてないかなー，とかですね。 けっこう心配だから逆に疲れるときあります稀。 離れていても考えてます。一息ついてるけど, ぞっかでやっぱ考光てますね。

$\mathrm{P}$ ：ほんとに子どもって『あんたじゃないとダメー!』 みたいな感じで来るじゃないですか。旦那もイ ヤ，おばあちゃんもイヤ，ママじゃないとイヤみ たいな感じが, ほんっとに私を必要としてるって 感じがして。

3 )【探し求めている充実感】

このカテゴリーは,《ひとりの個人としての私》,《自 分自身を見つめること》という2つのクラスターから 構成され，育児をしている今の自分が，どのような時 を過ごしたいと思っているのか，育児体験を通じて自 分自身を見つめ，得られた新たな価值観について語ら れた。

クラスター《ひとりの個人としての私》は，〈自分に とって意味ある時間〉を感じた体験について，〈育児以 外での自分の価値〉を考えた体験について語られた。 〈自分にとって意味ある時間〉というテーマを代表す る発言は以下の通りであった。

$\mathrm{P}$ ：母親だから当然やってくれる，食事の用意にして も，あと(一緒に)お風吕に入るっていうのも，そ れって母の時間を私に割いてくれてるわけですか ら，(中略）ほんとにありがたいことなんだってい うのに気づけたし，ただ，母からしたら『子ぞも だから当然でしょ』つて言ってくれるその気持
ち（私にも）今あります。この子に一緒にお風吕 入ったりご飯作ったりっていうのは，私の時間を この子に割いてることなんですけど，それはだつ て当然だし，きっと同じ気持ちなんだろうな あ,って。

育児に忙殺される時間を日々過ごすことは，自分が したいことを好きなように過ごすこととは違い，子ど ものために自分の時間を削るような思いがする日々で あると参加者は感じていた。そして過去に子どもで あった自分も同じょうに実母の貴重な生きる時間をも らっていたことに気づいた。参加者にとってこの体験 は日々生きる時間が，それぞれの人にとつて貴重であ ることの意味に気づく体験となり，子どもを育てるこ とは，その貴重な時間を費やすほどに重みのあること であることも感じていた。

また，次の参加者は，子どもを家族に預けて遠出を したときに，一人で過ごす時間の意味について考えた 体験を語っていた。

$\mathrm{P}$ ：ぞの電車に何時のに乗って，とか空港から乗った 瞬間とかに，フッて，なんかこう息をついて， ハッ（子どもが）いないんだ，って思ったりして， そしたらなんか色々考光始めて，こういう時間が あってこ危，いろいろ自分が偏っているとか，普 段考えてないことが出てきたりして，時々人に， 家族に (子どもを) みてもらうとか，それが無理な ら保育施設を使っても，それって(自分にとって) 意味があることだな，って。

この参加者にとって，子どもがいる忙しい日常から 離れて一人で過ごす時間は自分自身や日常を振り返る 内省をする時間としての意味を与え，参加者はこの体 験を通して，自分にとって一人で過ごす時間は必要な ものであり，子どもを預けることをしてでも時々は作 り出す意味があると感じていた。

〈育児以外での自分の価値〉というテーマの代表発 言は以下の通りであった。

$\mathrm{P}$ ：仕事してるとこうなんか，人のためになんかやっ てる自分がいるって思えるから，仕事やっぱりし たいな，とは思います。

この参加者は，子どもと二人だけで過ごす毎日はた だ同じように過ぎていくと感じているとも語り, 家事 や育児は感謝されることもほとんどなく，仕事をして いれば人との関わりの中で自分が誰かの役に立ってい ることを実感できることを語っていた。

$\mathrm{P}$ ：母の影響もあって，働きながら子ぞも育てるって 
大変だし (子ぞもが)かわいそう，って思ってまし たけど，そういう方が一人，すぐ身近にいたんで すけどしょっちゅう熱出したからお迎えに行か れたりして。そんなんしてまでしなくていい や，って思ってたんですけど (中略)，それだけの 意味がその人にとってはあったんだな，っていう のは理解できるようになりました。(しばらく沈 黙)やっぱり，育児は，自分の価值を感じにくい。 この参加者は，働くことは「自分のこととしての時 間」を得ること，とも述べ，以前は，働きながら子ども を育てることはしたくないと考えていたが，子どもを 育てるようになった今は, 同僚がなぜ大変な思いをし てまで㗢きながら育児をする選択をしていたのかと考 え，その大変さにもまして，充実した自分の時間を得 ることの意味を感じるようになったことを語っていた。

参加者らにとって, 仕事をすることは人のために役 立つという自分の価值や自分が充実して過ごす時間を 感じられることであると語られていた。

クラスター《自分自身を見つめること》は，育児を する日常で〈見えてきた過去の自分の姿〉について， またそれを認識するためには〈広い視野で考える余 裕〉が必要であったという体験が語られた。

〈見えてきた過去の自分の姿〉というテーマを代表 する発言は以下の通りであった。

ある参加者は，産後8か月までの育児体験が自分に とってどのようなものであったか，以下のように 語つていた。

P：だれかに寄り添ってこんなに生きることってな い，なかったと思うので，その，寄り添うってど ういう意味なんだとか，助けるってどういう意味 なんだろうって考光る時間，今までとは違う。

これまでの自分は, もしかしたら自分本位に生きて きたのかもしれない，と語る中で，参加者はこれまで 誰かのためにこんなに生きたことがないと感じ，育児 を体験したことは，人に寄り添うこととはどういうこ とか，と考える時間になったという。この参加者に とつての育児体験は, 過去の自分の生き方を振り返る 体験にもなっていた。

また, 別の参加者は, 育児を体験する前は, 育児を している人の大変さを自分が理解していなかったと気 づいたエピソードについて以下のように語つていた。

$\mathrm{P}$ ：例えば電車の中で，泣いている子とか見て，(中 略) 今は大変だね, つていう感じとか，それはた ぶん，やっぱ子どももたないと分からない，よ
ね。(今までは) 大人の中だけて生きてきてたから。 それがなんか(今は)子ぞもがいる中で生きている から，共感できる。

〈広い視野で考える余裕〉というテーマについての 代表発言は以下の通りであった。

P：(子ぞもが) 泣いたりしたらやっぱり困ったり， ずーっとしてたんですけど，なんで泣いているの か分からなくて。でも，文机をきっかけに，ちゃ んと子どもを見てから，なんで泣いているのか な，って考える時間になりましたね。

この参加者は, 産後の休息のために産後ケアセン ターを訪れたとき, 子どもを助産師に預け, 部屋にひ とりで横になっていたときの体験を語っていた。わが 子とはじめて距離を置き, 子どもの泣き声を遠くから 聞いているうちに，なぜ，泣いているんだろう，と思 い，そう考えているうちに子どもにも泣く理由がある のではないか, と気づいた体験を語つていた。

また, 次の参加者は, 地域の育児サークル活動に参 加したとき，育児を楽しんでいる自分に気づいた出来 事として以下のように語っていた。

$\mathrm{P}$ ：いろいろ話したり遊ばせたりして帰ってくると, こんな人もいて，あんな人もいて，で，私はこん な感じ，っていうのが相対的に自分の中でイメー ジできたときに，すごく楽しくなってきた。ほか のお母さんを見ることで，自分もなんか自然に笑 顔で接することができるようになる，そんな感覚 なんですけど。とにかく，人と話すことももちろ ん楽しいし，気持ちが楽になるけど，そういうお 母さんたちを見るってことも，自分をみつけるっ ていう感じですね。

この参加者は, 子どもと二人きりで家にいると, 自 分が楽しい気持ちかどうかも分からなくなることがあ ると語り, 他の母親が子どもと笑顔で遊んでる様子を 見ていると自分も自然に笑顔になっていることに気づ き，ああ，私も楽しいのだと自覚できたのだという。 子どもと二人きりの生活では, 見えてこなかった自分 の姿を，他の人たちと関わることによって視野が広が り見ることができるようになった体験として語られて いた。

\section{V. 考 察}

\section{1. 親であることと個人であること}

本研究参加者は, 育児が楽しく子どもが可愛いと感 
じると同時に，その楽しさを「時々忘れそうになる」 ような育児の負担感も感じていた。子どもをもつ前の 生活について述べた「あの時に戻れるなら戻って楽し みたい。けど,こっちには戻ってきたい」という発言 のように，過去の楽しさの㳖失感と育児に向かう気持 ちとの間で摇れ動く心情が示されていた。あの時」 「こっち」と場所や時間として示される子どもをもつ 前の生活と現在の子育てをしている生活は, この参加 者にとって別世界であるかのように語られていた。そ れは，育児を始める前には当たり前であった身軽に出 かけ，思うままに好きなことが出来ていた生活に決別 し，育児をする毎日の自己の受容には至っていない心 情であり，この女性にとって，二つの世界は統合され てないようにみえる。

育児期での自由の䘫失感は,「親になることによる 発達のひとつの側面」(森下，2006）であり，多くの人 が育児をしていく中で，思い通りにならないことに折 り合いをつけることができるようになったと実感する （鈴木他，2009）とされる。しかし，本研究参加者の 「手を抜くことを覚えたな，とは思いますけど，もう 私，母親になったっていう感じまだしない」という発 言は，折り合いをつけてうまくやっている，という感 覚からは遠く，この女性にとって育児の「手を抜く」 ことは，自身が描く母親像にはまだ到達していないと 考えていることが推察された。この参加者は, 実際の わが子との関わりの中で,「手を抜く」という自分独自 の対処方法を見出し, Mercer (1981)の母親役割獲得 過程理論でいう，第3段階の「非形式的役割段階」の プロセスを踏んでいると考えることも可能であるが, この女性自身の感覚としては,「母親になったってい う感じ」は，「まだ」得られておらず，目指している肯 定的な自己像を獲得してはいないように思われた。

また，実母が貴重な人生の「時間を私に割いて」育て てくれたと気づいた参加者の発言は,「私の時間をこの 子に割いている」という自分の体験に基づいた発見で あり，育児をして過ごす今の時間は，それまで職業人 として生きてきた自分にとっても貴重な人生の時間で あると意識された発言であったと考える。原口他 （2005）は，育児期女性は理想のありたい姿と現実の生 活とのギャップに葛藤を感じているという研究結果か ら，現代女性の意識として，「母として生きることのみ では, ありたい自分の姿とは異なり, 個人として生き ることへの志向が高まっている」と述べている。本研 究の結果からも, 育児期女性は, 親として生きる時間
のなかで，自らの人生の充実する時間とはどのような ものか探し求めていることが示唆された。育児の楽し さや充実感は, 育児によって感じる制約感や拘束感と 表裏一体であり, 育児をする現代女性にとって, 親と して生きることと個人として自分の人生をどのように 生きていくかを考え続けることは，避けて通ることの できないテーマとなっているのではないかと考える。

子育てによる制約感はストレスを産むとされる反 面, 浅賀他 (2008) は, 育児における心理的負担感を 感じる機会が多いことによって, より自らの成長を強 く認識する可能性について述べている。育児期にある 女性は，親として生きる自分を意識することで，親と してではない個人の人生をどのように生きるのか見つ める契機を得ていると考えることもできる。子どもを 家族に預けて遠出をした参加者が，自分について「考 え始め」，そのような時間を得たことが自分にとつて は「意味があること」と語った発言はその象徵であっ たように思われた。

参加者の中には, 子どものためと考え, 苦手な人付 き合いに挑戦し「この人を通して人閒関係が変わっ て強くなったなあ, って思う!」と育児による自己成 長を実感する者もみられていた。この発言から，育児 を通して女性が自己成長を実感し, 認知することが女 性の人生の充実感や喜びにつながる可能性があるので はないかと推察された。育児体験での自己成長による 喜びは,「母親として」や「親として」という限定的な 枠組みで成長の意味づけを外側から規定されるのでは なく, 育児期女性自身が自己の内面からの成長実感を 得ることが女性にとって意味があるのではないかと考 える。徳田 (2004) は, 子育てにおける学びや成長と いった意味づけが, 育児による制約感や心理的負担を 母親によって果たすべき義務や達成課題として捉えら れる可能性について述べている。その上で子どもと関 わる自己の変化を心理的負担も含めて, 肯定的, 積極 的に受け入れることが自己受容につながることも指摘 している。そのような視点に立って考えれば,「母親 としての成長」は, 社会・文化的な側面から規範的に 規定されたものという意味合いをもち，「母親として」 とは限定されない, 人として個人としての成長の喜び は，素直な充実感を伴い自己受容に結びつきやすいの ではないかと考える。

\section{2. 育児期女性にとっての人間関係}

初産婦が育児に慣れたと感じるのは産後 6 か月後頃 
（我部山，2002）とされるが，産後8か月を過ぎた本研 究参加者の中には，自分が行う育児について「本当に 正しいのか，正しくないのか，誰も教えてくれない」 と迷いを感じている者もみられていた。初産婦に とっての育児は, 子ぞもの成長に伴い常に新しい局面 が現れ対処が必要となるため, どこまで進んでも暗中 模索をしている気持ちは拭えない側面がある。そのよ うな状況の中で，育児をする女性は「自分自身に確証 を得るための拠り所を求める」(鈴木他，2009）。その 求めている拠り所とは，単なる育児技術的な情報や方 法ではなく，育児に迷いを感じる自分の気持ちを支え てくれる周囲の人の存在や人間関係なのではないかと 考える。本研究結果においては, 泣いている子どもに 困っているときに，実母からの「何気なしにかけてく れる言葉」として，また「洋服ひとつ着せるのにもこ んなに大変なんだ」と育児の大変さを自分と同じ地平 で実感する夫の言葉として示されていた。山崎 （1997）は，育児期女性と生活する家族の価值観が女 性の自己概念に対して与える影響が大きいことを指摘 している。育児期女性と日常を共にする家族が育児を することの大変さをどのように理解し，また育児をす ることの価值をどう考えているかということが，育児 期女性の家族との関係性にも反映していると考えるこ ともできる。そのため，育児期女性への支援は，女性 と家族との関係性にも注目していく必要があるであろ う。また，育児期女性が育児をする自分をどのように 意味づけるのかという点において, 家族との関係性を みていくことは重要な意味を持っていると考えること ができる。

また, 現代女性の特徴のひとつとして他者評価に よってアイデンティティを得やすい（山田，2000）と いう傾向が指摘されている。一般的に日常茶飯事の中 に埋もれがちであり, 他者評価が得にくい育児は, 「自分の価值を感じにくい」と思う参加者もいた。そ のように感じる女性にとっては,「仕事してるとこう なんか, 人のためになんかやってる自分がいる」とい う代表発言にみられるように，仕事をしている自分で いることが, 何らかの成果や他者評価を明確に得るこ とができると感じるため，やりがいや充実をそこに見 出しているのではないかと窥えた。

職業経験において,「ひとのためになんかやってい る自分」を感じ，他者評価に依って生きてきた女性が 育児をする生活になったとき，うまくいっているのか どうか明確な判断の基準がないと感じ，迷いながら育
児を体験していく。うまくいっている確証が得られな いときには,「自分の価值を感じにくい」場合もある。 それは，自己像の見直しを迫られることでもあり，う まくいかないと感じる状況が高じると精神的に不安定 な状態に陥っていく場合もある。中井 (1992) は, 精 神の健康を保つ基準のひとつに「可逆的な退行ができ ること」をあげている。時に子どものように人に甘 え, 頼ることができることは一つの能力であるとも考 えられる。他者のために役立っている自分という視点 から移動し, 自分も誰かに助けられる存在であること に気づき，他者に支えられる自己を受容していくとい うプロセスが，育児を体験する中で生まれてくるので はないだろうか。その気づきを育児期女性に与えるの は,「洋服ひとつ着せるのにもこんなに大変なんだ」と 自分と同じように育児の大変さを実感する夫や, 貴重 な人生の「時間を私に割いてくれ」, 自分を育てた実 母の存在であるだろう。また，同じ空間で過ごすこと で「自分もなんか自然に(子どもと) 笑顔で接するこ とができるようになる」と思えるような友人の存在も 同様であると考えられる。

育児期女性が家族を含めた他者との関係性におい て, 自己像の再構築への契機を得, 育児をする自分の 意味づけをおこなっていくとすれば，育児期女性の人 間関係に注目をして支援をしていくことは意義のある ことと考えられる。

\section{3. 育児期女性へのヶアについての示唆}

春日（2017）は, 育児期女性の自己受容に関する研 究結果から,「個人としての自己と母としての自己の 受容が密接に関連し合う」ことを述べている。本研究 結果においても, 育児期にある参加者たちは, わが子 から必要とされる親として生きる自分を意識する一方 で, 個人としての充実した時間を求め探していたこと が窺えた。

妊産裖婦や新生児をケア対象とする助産師は「親と なっていく女性」への支援を行うが，育児期女性が， 一人の個人としてもいきいきと充実を感じて生活をす ることができているのかどうかという視点もあわせ持 ち, ケアをおこなっていくことは必要なことであると 考える。また，育児期女性が自分の人生での育児の意 味づけをどのようにおこなっているか，育児をする自 分をどのように捉えているかということに理解を向け ることは, 育児期女性のケアを行う上で, 大切にした い点であると考える。 
本研究結果から, 育児期女性は家族を含めた他者と の関係性において，育児をする自分の意味づけをおこ なっていくことが示唆された。日本の子育て支援は 地域子育て拠点事業のように母子を対象としている点 が特徵」（木脇他，2014）とされるが，育児期女性を支 える周囲の人をも含めていかに支援をしていくか考慮

し，育児をする家族を支援するという視点を持ちつ つ，育児期女性への支援をおこなっていくことが大切 ではないかと考える。

\section{4. 研究の限界と課題}

本研究は育児期女性を研究参加者として現象学的ア プローチによりおこなった研究であるが，育児をする 女性を母親としてではなく個人として捉え，女性の人 生における育児体験の意味を明らかにしていくために は，更に異なる生活背景や様々な人生の局面にある対 象者に対して研究を行い, 知見を蓄積していく必要が あると考える。

\section{VI. 結 論}

はじめての育児体験が女性自身の人生にもたらした 意味として,【子どもを持ってはじめて感じた周囲か らのまなざし】、張りつめた日々から子どもと生きる 親としての日常】【探し求めている充実感】の3つの カテゴリーが抽出された。

育児期女性は，親としてどのように生きるか意識 し，迷いや不安を感じると同時に，個人としての人生 をどのように生きていくかも考え，女性たち自身の充 実感も求めていた。現代女性が自分の人生における育 児体験の意味をどう捉えているか理解し，女性個人を 尊重する視点をもつことが育児期女性の支援として大 切である。また，育児期女性への支援は，家族を含め た周囲との関係性を捉えることが重要であると考えら れるため，育児期女性のみに焦点を当てるだけではな く，女性の家族や周囲の人をも含めた支援として考え ていく必要がある。

\section{謝 辞}

本研究にご協力，ご参加いただきました皆様，並び に協力施設のスタッフの皆様に心より感謝申し上げま す。なお，本研究は修士論文に加筆修正を加えたもの であり, 内容の一部は, 第 33 回日本助産学会学術集 会で発表しました。

\section{利益相反}

論文内容に関し開示すべき利益相反の事項はありま せん。

\section{文 献}

浅賀万理江，三浦香苗 (2008)。育児における女性の心理 的体験に関する研究の今後. 昭和女子大学生活心理 研究所紀要, 11, 49-56.

Colaizzi, P.F. (1978). Pshycological research as the phenomenologist views it. In Valle, R. \& King, M. (Eds.), Existential phenomenogical alternative for psycology. pp.48-71, Oxford University Press.

原口由紀子，松浦治代，矢倉紀子，佐々木くみ子，笠置綱 清 (2005)。母親の個人としての生き方志向と育児不 安との関連．小児保健研究，64(2)，265-271.

Holloway, I. \& Wheeler, S. (2002). Qualitative Research in Nursing. 2nd edition. pp.170-187, Oxford, UK: Blackwell Science Ltd.

井上清美 (2003)。母親の「自己犠牲」規範意識の趨勢と規 定要因。年報社会学論集，16，150-161.

我部山キヨ子 $(2002)$ ，産後の育児に関する研究一育児適 応を促進・遅延する因子一。 母性衛生, 43(2), 314320.

柏木惠子 (2001). 子どもという価值 少子化時代の女性 の心理. pp.34-36, 中央公論新社.

柏木惠子，若松素子 (1994)。「親となる」ことによる人格発 達 生涯発達的視点から親を研究する試み. 発達心 理学研究, 5(1), 72-83.

春日由美 (2017)。育児期女性の自己受容に関する一研究 一子ぞも受容・被受容感との関連を通して一。 南九 州大学人間発達研究, $7,15-21$.

木脇奈智子，太田由加里 (2014)。多様化する子育て支援 の現状と課題 : 第 3 報ーフィンランドの家族支援「ネ ウヴォラ」に着目して一. 藤女子大学 $\mathrm{QOL}$ 研究所紀 要, 9(1), 35-43.

Lincoln, Y.S. \& Guba, E.G. (1985). Naturalistic inquiry. pp.300-320, CA: SAGE Publications.

Mercer, R.T. (1981). A theoretical framework for studying factors that impact on the maternal role. Nursing Research, 30(2), 73-77.

宮中文子 (2001)。「母親の発達」に影響する父親および家族 の要因一出産後 10 力月の調査による分析一. 母性衛 生，42(4)，677-685.

森下葉子 (2006)。父親になることによる発達とそ扎に関 
わる要因. 発達心理学研究, 17(2), 182-192.

中井久夫 (1992)。中井久夫著作集 6 巻 個人とその家族. pp.175-183, 岩崎学術出版社.

中谷奈美子，中谷素之 (2006)。母親の被害的認知が虐待 的行為に及ぼす影響. 発達心理学研究, 17(2), 148158.

岡本裕子 (1996)。育児期における女性のアイデンティ ティ様態と家族関係に関する研究。日本家政学会誌, 47(9), 849-860.

小野田奈穂 (2013)。育児期女性の「個人としての自分」と 育児ストレスとの関連一理想と現実のギャップから の検討一. 家族心理学研究, 27(2), 123-136. 大日向雅美 (1988)。母性の研究. pp.107-134, 川島書店. Rubin, R. (1986)／新道幸恵・後藤桂子訳 (1997)。母性 論 母性の主観的体験. pp.145-148, 東京: 医学書院. Sandelowski, M. (1995) / 谷津裕子 - 江藤裕之訳 (2013). 質的研究をめぐる10のキークエスチョン.pp.45-60, 東京 : 医学書院.

鈴木由紀乃, 小林康江 (2009). 産後4か月の母親が母親と しての自信を得るプロセス。 日本助産学会誌，23(2), 251-260.

戸田まり (2009)。親子関係研究の視座. 教育心理学年報, 48, 173-181.

徳田治子 (2004)。ナラティヴから捉える子育て期女性の 意味づけ: 生涯発達の視点から. 発達心理学研究, 15(1), 13-26.

山田昌弘 (2000)。「よりよい子育て」に追い込まれる母親た 5. 目黒依子・矢澤澄子 (編)。少子化時代のジェン ダーと母親意識。新曜社．pp.69-77.

山崎あけみ (1997)。育児期の家族の中で生活している女性 の自己概念一「母親としての自己」・「母親として以外 の自己」の分析一. 日本看護科学会誌，17(4)，1-10. 